\title{
The Integration of the Bars of Former Socialist Countries into the European Union Framework and into the Council of Bars and Law Societies of Europe (CCBE)
}

\author{
Jana Wurstová
}

(C) ERA 2011

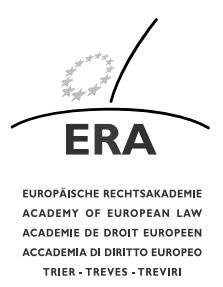

\begin{abstract}
The author describes the specific challenges which the Bars of the former socialist countries in Central and Eastern Europe, in particular of the four Višegrad countries, had to face after the fall of the Berlin Wall when their legal orders returned to the rule of law and had to prepare for accession to the European Union. At that stage, it was in particular the Council of the Bars and Law Societies of the EU (CCBE) which assisted in the transition, insisting on basic constitutive elements of the legal profession such as independence and self-regulation. The author also looks at deontological rules, training, free legal assistance, and the regulation of fees.
\end{abstract}

Keywords Bars - Legal profession - Central and Eastern Europe - CCBE · EU · Autonomy $\cdot$ Training $\cdot$ Fees

\section{Introduction}

Whenever one wishes to generalise in relation to anything and then analyse the thengeneralised issue, the risk arises of going astray. Insofar as concerns the legal professions in those countries which first underwent the socialist experience only to "return" to the democratic system later, none had had, prior to World War II, entirely identical legal cultures and traditions. As far as the legal profession is concerned, its development took place more or less in a similar fashion in these countries during the period of socialism, but it should be kept in mind that due to a number of reasons they did not begin at the same starting line after the major political changes in 1990. Among other reasons, this was because the mentality of these nations and their relationship to

JUDr. J. Wurstová, Head of International Department ( $₫)$

Czech Bar Association, Prague, Czech Republic

e-mail: wurstova@cak.cz 
democratic traditions had not been the same. Delving further into this would require an excursus into history - perhaps not into the medieval beginnings of legal consulting services, but certainly into the common roots of countries which later formed part of the Austro-Hungarian Empire, where the profession of a lawyer together with the role of providing legal assistance to the poor took a particular form and had official (legislative) foundations in the eighteenth century. The Europe of that time did not have these foundations in common, however. France - and not e.g., Germany, as many might imagine - influenced the Czech Republic, the Slovak Republic, Hungary and Poland via the Code Napoleon of 1806.

Because of the foregoing reasons, it is not easy to put all former socialist countries under one roof from the view of the integration of their legal professions and the bar associations. Such an approach should be limited to those countries that have, since 2004, become European Union Member States. A select group of countries, consisting of the so-called "Višegrad" states (i.e., the Czech Republic, Hungary, Poland and Slovakia) may serve as an example of these if one looks at the topics and problems with which they have had to cope, first, since the revolutionary changes that occurred at the end of 1989 and in early 1990, and secondly since the subsequent preparatory period for their accession to the European Union, in the course of which the respective bar associations were accepted as observing organisations in the Council of the Bars and Law Societies of the European Union (the CCBE). In the light of the common roots referred to above, the aforementioned countries and their lawyers understand each other very well insofar as relationships concerning courts and judges are concerned. JUDr. Karel Čermák, the former chairman of the Czech Bar Association, once told the following joke: "For whom does the judge provide reasons for his/her decision? In Britain, for the lawyers of the parties, in France, for the Appeal Court; and in Germany, for academics." Lawyers in the Višegrad states take the same approach as lawyers in France.

These countries and their lawyers remembered well the position of and ethics of the independent pre-World War II legal profession - or at least the older generation did. Fortunately, and long though the post-war period of socialism may have been, they lived to see the restoration of the legal profession's independence. On that basis they were well able to renew and reinvigorate the lawyers' sense of the duties and advantages of independence (so that the legal profession should not only become a gold mine in disregard of the right of all citizens to access to justice regardless of their means).

\section{Independence of the Legal Profession and the Position of Bar Associations}

It is not sufficient to consider merely old traditions and pre-war democratic models. It is necessary to also look for contemporary examples or models. Of the several international organisations of lawyers offering help after 1990 it was the CCBE who had a consistent opinion on who was and who was not a lawyer in the traditional, i.e., European, sense of the word, and on what the fundamental ethical values and duties of a lawyer were, defining his/her position specifically in relation to the general public so that he/she could not be mixed up with other legal professionals, e.g., in-house 
counsels. The CCBE insisted that any lawyers' organisation must comply with the requirements of the CCBE's paradigmatic Ethical Rules so as to be accepted as an observer at all, thereby providing certain guidelines for a national definition of the legal profession and regarding the position of bar associations towards the state in the former socialist countries mentioned above.

These requirements consist of the lawyer's independence, the professional secrecy, the duty to take out insurance to cover any potential damage caused to a client, the conditions for practice, education and bar examinations. This list does not include everything that defines the legal profession, but yet this is a never-ending effort or even a struggle for bar associations vis-à-vis the state. Governments have repeatedly tried to restrict the freedom of the legal profession or question the necessity of the bar association's existence, once claiming that "bar associations are clearly unnecessary", another time under the aegis of "the war against terrorism and money-laundering". Bar associations and the CCBE repeatedly fight with the European Commission as well (and achieve small victories). Although I would not like to give particular examples of this, there are many. And all this clearly reflects the different development of the legal profession in the United Kingdom and in Ireland, where something that was impossible until quite recently has started to take place, e.g., that two lawyers from a big law firm represent two clients as opposing parties to a dispute without this being considered a conflict of interests. The indispensability of bar associations is clear from the ongoing attention they pay to both positive and negative inputs related to lawyers and the legal profession as such and from their response to such inputs. They are guarantors of the quality of the profession with respect to the general public.

Laws on the legal profession and ethical rules have gradually stabilised and specified in detail the conditions for practising law, the ways in which the legal profession may be practised, and the scope of the various fields of legal practice in particular states. As far as the last item is concerned, so-called commercial lawyers existed until recently in the Slovak Republic and still exist in Poland (where they are called "radca prawny"). They cannot (in Poland) and could not (in Slovakia) provide the full range of services of the legal profession, as their services do not (or did not) include representation in criminal cases. Yet the bar associations representing both kinds of legal professions are members of the CCBE, which proves that the CCBE is not strictly closed to any forms and changes as long as the basic values of the legal profession are observed.

\section{Education of Lawyers and Approach to the Profession}

The quality of the legal profession is based on the education of its trainees, i.e., future lawyers, and on the high-quality lifelong education of lawyers. Such education does not take the same form in all of the Višegrad countries. In certain of them, the training of lawyers - i.e., adults - is subject to a minimum number of compulsory lessons attended or credit points acquired in a year. In other countries training occurs on a voluntary basis, with bar associations arranging for regular seminars to 
provide those who are interested with information on new legal developments. This is the case in the Czech Republic. The education of trainee lawyers there is compulsory and monitored, and no trainee lawyer is allowed to take a bar examination without presenting a certificate that he/she has attended the prescribed compulsory seminars.

The Academy of European Law has also been a regular provider of high-quality seminars (lifelong education) in the field of European law in particular in the Czech Republic.

Laws on the legal profession define in most cases who is and who is not, or who may or may not become, a lawyer. In other Central European countries, the attitude towards accepting the activities of lawyers coming from abroad was not as liberal as in the Czech Republic, which was and perhaps still is the most liberal country in this respect. Even though the European Establishment Directives are the same for lawyers in all European Union Member States, practice varies somewhat between individual bar associations and the same applies to professional and financial rules. Since Czech accession to the European Union, the rules governing the legal profession have distinguished between so-called European lawyers (regardless of whether they want to operate in the territory of another European Union Member State only for a short period of time, ad hoc and/or permanently) and lawyers from countries that are not European Union members. As a rule, the latter experience considerable limitations regarding the kind of law in which they may be engaged in the hosting country even after they have complied with all required conditions. For instance, in the Czech Republic a lawyer from Georgia may not practise any type of law other than the law of his/her own country as well as international law.

\section{Lawyers' Fees}

Lawyers' fees may be based on a free agreement made between the lawyer and the client or else they are fixed by a scale of fees under a regulation published by the Ministry of Justice. Until recently (and in some European Union Member States even now) the lawyer has not allowed to agree with the client on a fee which would correspond to a percentage of the amount the lawyer manages to gain for the client in the successful conduct of a judicial dispute. This form of remuneration, the so-called "pactum de quota litis", is now possible in the Czech Republic, but only to the limited extent stipulated by the Act on the Legal Profession.

\section{Free Legal Assistance}

Lawyers traditionally provide their services in the context of court proceedings either free of charge or for a reduced fee if they are ordered to provide this form of service by the court. In addition to the state system, there is a well-established system of free legal assistance provided by lawyers in the Czech Republic, which is financed exclusively from fees paid by lawyers to the Czech Bar Association. The Czech Republic is the only Member State of the European Union and the Council of Europe (which 
includes 47 states) to have such a system. The Czech Bar Association determines the lawyers who may provide such services on the request of clients in need (within a system which is regulated by professional rules and has been in operation since 1996). These services include both legal consultation services and services related to the representation of a citizen at court if the conditions stipulated by the Czech Bar Association are complied with by him/her. 